\title{
STUDY ON PEDESTRIAN AND SLOW MOVING TRAFFIC
}

\author{
R.R Singh ${ }^{1}$, Er Gurdeep Singh ${ }^{2}$ \\ ${ }^{1}$ Associate Professor, Civil Engineering Department, P.EC, University of Technology, Chandigarh, India \\ ${ }^{2}$ Persuing Post Graduation, Civil Engineering Department, P.EC, University of Technology, Chandigarh, India
}

\begin{abstract}
When the consideration take place about the traffic of Chandigarh, no one think about the traffic related issue on slow moving traffic like pedestrian, bicyclist and other slow moving traffic. Though the motor vehicles have the revolutionized the road transport, but the steep growth of traffic in Chandigarh in recent years has caused an increment in traffic congestion and the rate of accident. According to the black book 2013 compiled by road accident analysis by Chandigarh traffic police, Geographical area of the Chandigarh is 114 sq. kms. Total population of Chandigarh is over 11 lakhs. Vehicular population of the city is more than 8.8 Lacs which is the highest per capita vehicular population in the country. Everyday more than 100 vehicles are added in U.T. Chandigarh. Total road length of Chandigarh is $1536 \mathrm{kms}$. More than 130 lives are being lost every year in Chandigarh

Walking is an important mode of transport. In sector areas a significant proportion of trips up to 1-2Kms in length are performed on foot. Moreover every journey necessarily starts and ends as a walk trip. Since pedestrian are more vulnerable to being involved in accidents, it is imperative that adequate consideration should be given to their safety through provision of facilities like guard rails, secured crossing areas, footpath and grade separations. Pedestrian facilities should be planned in an integrated manner so as to ensure a continuous pedestrian flow. It should be useful therefore to look at pedestrian needs for an area as a whole and prepare an overall strategic plan. The basic aim should be to reduce pedestrian conflicts with vehicular traffic to the minimum. Efforts should be made to create such conditions that pedestrian are not forced to walk in unsafe circumstances and that the motorist respects the position of pedestrian. While planning the convenient of pedestrian should be paramount consideration. Otherwise the facilities provided will not be fully used. Suggestions formulated as traffic management schemes to provide safety to the pedestrians by reducing conflict in between vehicle movement and pedestrians
\end{abstract}

Key Words: Sidewalks, pedestrian level of service, pedestrian environment, and unit flow rate, cycle track and it's Facility Survey

\section{GENERAL}

A significant proportion of every modal trip is made by walking. Therefore the needs of the pedestrian, like the needs of motor vehicles, should be considered in the design of the urban environment and transportation facilities. Efforts should be directed toward the safe, accessible, and convenient mobility for pedestrians. Also residents and visitors should be encouraged to walk for trips of reasonable length. Evaluating the pedestrian facilities and walking conditions is much more complex than the vehicular roadway, because while occupants of automobiles are separated in their insulated environment, the pedestrian is exposed to a variety of diverse environmental conditions. Pedestrian LOS is an overall measure of walking conditions on a route, path, or facility. In this paper current practices for providing pedestrian facilities and methodologies of assessing level of service (LOS) for pedestrians are discussed. Their strengths and weaknesses are examined and suggestions are made to arrive at a more satisfactory service level analysis of pedestrian facilities. By understanding and going beyond existing LOS methodologies, the transportation planners and managers can think for an appropriate methodology that adequately assesses the service level for walking
The cyclist and other slow moving traffic have great impact on the fast moving traffic so that it is necessary to avoid conflicts point with fast moving traffic and assign separate path for it.

\subsection{Scope of Study}

As the pedestrian and slow moving traffic study has never studied in Chandigarh. And it also not been study in most of the states of India but it have vital scope as the traffic increases on the road. The steep growth of traffic in Chandigarh in recent years has caused an increment in traffic congestion and the rate of accident. For the safer moment of pedestrian is required to carry out survey and then with decision in the CBD to locate/allot places on the roads and vendors so that the pedestrian do not keep crossing the roads and hence all the pedestrian will have safer movement. The fatal accident cause by the conflict point of traffic with pedestrian, to reduce the accident possibility, the study on the topic has some scope and for future refers study. It could be successive study for Chandigarh like tri-cities where the territory bound very less area and traffic increases rapidly. This could be a major study that can be carried out by local government. Pedestrian traffic control issues must be continually monitored to ensure that devices remain effective and that available funds derive the best value Pedestrian crossing 
presents one of the greatest challenges for the traffic and safety engineering communities. The challenge is created by the two modes of travel that share the road. The issues associated with pedestrian crossing activities generally create considerable emotional concern within the community, especially when the community is reacting to an incident involving pedestrian injury. Pedestrian crossing safety relies on the judgment exercised by pedestrians and drivers. To interact safely requires an exchange of information between the pedestrian and the motorist. Although traffic control devices can help to promote an exchange of information, educating pedestrians and drivers is paramount to providing for a safe operation. Since pedestrians involved in traffic accidents are inevitably injured, safety must receive a high priority in analyzing pedestrian crossing issues. Crosswalk safety is usually evaluated using engineering factors, since no reliable method exists to forecast pedestrian accident trends. Pedestrian accident history is generally categorized by age but seldom does it consider all variables such as level of use by population or age group. The school-age group experiences, on a proportional basis, a higher accident rate. Because of this it has received additional attention in the form of specific signs and legislation governing school pedestrian activities. Concern has also been focused on the group aged 65 and over, due mainly to the general reduction in their crossing skills. As with other forms of traffic control, the uniform application of traffic control devices for pedestrian crossings promotes the orderly and predictable movement of traffic.

According to an article of times of India "A study by traffic police has revealed that most people who died in road accidents in Chandigarh over past five years were pedestrians. The data for the study was from January 2007 to September 2011 and all cases registered in the connection with road accidents were scrutinized. The study concluded that 555 persons lost their lives in accidents during past five years and 195 of them were pedestrians. It also established that cyclists were the second worst-affected group. Largest numbers of pedestrian casualties were reported in 2009, when 48, including 16 women, eight children and 34 men died. Twenty-eight pedestrians were killed during the first nine months of 2011.The study showed that most pedestrians died in road accidents at Madhya Marg, in Industrial Area, Colony No. 5 and in the internal roads of some sectors"

Approximately 1,25,000 lives are lost every year in India and the total loss of productivity due to road accidents is $3 \%$ of GDP (approx. Rs. 1 lakha crore) every year In India, 10.83 persons killed in road accidents per 100000 . One road accident takes place every minute and one fatality every four minutes in the country. As per survey of WHO nearly 3,500 people die on the world's roads every day. Tens of millions of people are injured or disabled every year. Children, pedestrians, cyclists and the elderly are among the most vulnerable of road users. So there is a need and scope of study according to the history of accident in Chandigarh.

\subsection{General- Chandigarh}

The beautiful city of Chandigarh is one of the best places to live in India. Touching the borders of Haryana, Punjab and Himachal Pradesh, Chandigarh is a city and also a union territory in India. The city also holds the crown of one of the cleanest and well planned cities of India. It serves the capital of two states: Haryana and Punjab. The city beautiful is location at about $256 \mathrm{~km}$ North of New Delhi. Toward the North-East the Foothills of the Himalayas- the Shivalik range rises gradually to about $1524 \mathrm{~m}$ forming a splendid nature backdrop. The general ground level ranging from 305 to $306 \mathrm{~m}$ with a $1 \%$ gradient provide adequate drainage. The city was planned and designed by late French Architect Le Corbusier. He was assisted by his cousin Pierre Jeannert and English Couple E.Maxwell Fry and JaneB.Drew. Today Chandigarh is considered to be one of the best planned cities in the world. The basic planning unit of the city is the sector, each measure $800 \mathrm{~m}$ x 1200m enclosed by road for moving traffic. The typical sector is a self sufficient neighborhood, with its own shopping centre, schools and other community facilities. Just like other cities and union territories of India, Population of Chandigarh too has increased in the last decade from 2001 to 2011. However it has grown on an average of $4 \%$ every year, but the current estimates suggest that Population of Chandigarh is increasing at a very high rate

\subsection{Traffic in Chandigarh}

As a city, Chandigarh has been a remarkable success story, providing a high quality of life to citizens and has grown very rapidly. Because of these two reasons it attracts not only middle class and upper class families but also workmen skilled and unskilled both. The city continuing to grow at a feverish pace. The estimated urban population in 1997 was 7.20 lacs. The villages around city are growing ever faster. Steep increases in population of city itself and rapid growth of satellite town like Panchkula and Mohali is resulting in large number of trip making. Improvement in living standards has resulted in an unprecedented boom in motorvehicle ownership in recent year, encouraging even more number of trips making. As it is clear from motor-vehicle registration data available, the car ownership is increasing day by day and there is steep rise in traffic in the city. In the fatal accidents in Chandigarh as many as $45 \%$ involves cyclists. The glaring defect's in street system, insufficient junction spacing and above all the arbitrary treatment of the existing important intersections are the major factors contributing to a large number of both serious and fatal accidents. The proportion of cycle traffic is three to six times the motor vehicular traffic. A large variation of speed for different categories of traffic increase the severity of accidents and number of conflict with pedestrian

\subsection{Madhya Marg road, Chandigarh}

Madhya Marg is considered as one of the very important road of Chandigarh, connecting P.G.I. at one end to Panchkula on the other end. This is one of the heavily trafficked roads in Chandigarh providing access to many 
educational institutes, shopping centers and offices. Traffic volume, speed and traffic density are very important traffic flow characteristics for the assessment of any important road. Traffic studies in respect of volume and speed conducted on Madhya Marg in Chandigarh in the past reveal the following.

1. Traffic on Madhya Marg is of mixed type. It consists of fast moving vehicle like trucks, buses, cars, vans, scooters and slow moving vehicle like cycle, rickshaw and horse driven vehicle.

2. From the classified volume count of traffic on Madhya Marg on different intersection during peak hour, it has been observed that car/jeep volume account for nearly $25 \%$ of total traffic volume, scooter/Moto cycle/Moped accounts for nearly $50 \%$ of total traffic volume.

3. Traffic on Saturdays is nearly 50 to $70 \%$ of the traffic on other working days.

4. There is considerable amount of cycle traffic in Chandigarh. The analysis of volume counts indicates that the percentage of cycles and slow moving is as high as 60 $70 \%$ on certain stretches of road. This is due to the fact that large number of people comes to Chandigarh daily from adjoining villages and satellite town Mohali and Panchkula. The speed of cycle varies from $5 \mathrm{kmph}$ to $10 \mathrm{kmph}$ which causes congestions on roads also cyclists are largely involved in accidents.

The selection of the location based on the area to study where the problem and pedestrian has been seen. The road sections have been taken on the Madhya Marg and near Madhya Marg, roundabout of grain market and Educational institutional area, 26 sector, Chandigarh.

\subsection{Design for Pedestrian facilities}

For safety of pedestrian, separate footways should be provided alongside the carriageway of urban streets. They should be provided on the either side of the road and should preferably be raised above the general carriageway level. To attract full use pedestrian, they should be property surfaced or paved. They should be sloped adequately to drain away the rain water. Crossfalls within the range of 1 in 40 are satisfactory.

The widths of the footways as per current U.K practices are given in Table 1

The capacity of footways recommended by I.R.C are given in Table 2
Table -1: Recommended Footway widths [1]

\begin{tabular}{|l|l|}
\hline Type of road & $\begin{array}{l}\text { Recommended minimum } \\
\text { footway width }\end{array}$ \\
\hline Primary Distributor & No footway \\
All-purpose road & $2.7 \mathrm{~m}$ \\
District distributor & $\begin{array}{l}2.7 \mathrm{~m} \text { in principal business and } \\
\text { industrial districts } \\
2.4 \text { in residential districts. } \\
\text { Local distributor }\end{array}$ \\
$\begin{array}{l}\text { Access road } \\
\text { industrial districts } \\
1.8 \mathrm{~m} \text { in residential districts } \\
\text { Principal mean of access: } \\
2.7 \mathrm{~m} \text { in principal business } \\
\text { districts } \\
1.8 \mathrm{~m} \text { in industrial districts } \\
1.8 \mathrm{~m} \text { normally in residential } \\
\text { districts } \\
3.7-4.5 \mathrm{~m} \text { adjoining shopping } \\
\text { frontage. } \\
\text { Secondary mean of access : } \\
0.9 \mathrm{~m} \text { verge instead of footway } \\
\text { on road in principal business } \\
\text { and industrial districts. } \\
0.6 \mathrm{~m} \text { verge instead of footway } \\
\text { on road in residential districts }\end{array}$ \\
\hline
\end{tabular}

Table- 2: Capacity of footpath [2]

\begin{tabular}{|l|l|l|}
\hline $\begin{array}{l}\text { Width of } \\
\text { Footpath(m) }\end{array}$ & $\begin{array}{l}\text { Capacity in number of person } \\
\text { per hour }\end{array}$ \\
\cline { 2 - 3 } & $\begin{array}{l}\text { All in one } \\
\text { direction }\end{array}$ & In both direction \\
\hline 1.50 & 1,200 & 800 \\
2.00 & 2,400 & 1,600 \\
2.50 & 3,600 & 2,400 \\
3.00 & 4,800 & 3,200 \\
4.00 & 6,000 & 4,000 \\
\hline
\end{tabular}

\subsection{Design Criteria for Separate cycle Tracks}

Segregation of cycle track promotes safety. In view of the large number of cycle on the streets of Indian towns and cities, it is desirable that separate cycle track be provided wherever feasible. The design criteria for cycle track are laid down by the Indian Road congress. [3].The design criteria commonly adopted are:

Table-3

\begin{tabular}{|l|l|}
\hline Design Element & Guideline \\
\hline $\begin{array}{l}\text { 1.Justification for } \\
\text { separate cycle } \\
\text { track }\end{array}$ & $\begin{array}{l}\text { Where the peak hour cycle traffic is } \\
400 \text { or on routes with a vehicle with } \\
\text { a vehicle traffic of 100-200vehi/hr. } \\
\text { Where the motor vehicle traffic is } \\
\text { more than 200 veh/hour, separate } \\
\text { cycle track are justified even if the } \\
\text { cycle traffic is only 100 per hour }\end{array}$ \\
\hline
\end{tabular}




\begin{tabular}{|c|c|c|c|}
\hline \multirow[t]{4}{*}{$\begin{array}{l}\text { 2.Capacity (per } \\
\text { day) }\end{array}$} & Lane & $\begin{array}{l}\text { One-way } \\
\text { traffic }\end{array}$ & $\begin{array}{l}\text { two-way } \\
\text { traffic }\end{array}$ \\
\hline & $\begin{array}{l}2- \\
\text { lanes }\end{array}$ & $2000-5000$ & $500-2000$ \\
\hline & $\begin{array}{l}\text { 3- } \\
\text { lanes }\end{array}$ & $>5000$ & $2000-5000$ \\
\hline & $\begin{array}{l}\text { 4- } \\
\text { lanes }\end{array}$ & - & $>5000$ \\
\hline 4.Verticle curves & \multicolumn{3}{|c|}{$\begin{array}{l}\text { 1)Minimum } 10 \mathrm{~m} \\
\text { 2) Where the gradient is steeper } \\
\text { than } 1 \mathrm{in} 40 \text {, minimum radius shal } \\
\text { be } 15 \mathrm{~m} \text {. } \\
\text { Minimum Radius } \\
\text { 1) Summit curves }: 200 \mathrm{~m} \\
\text { 2) Valley curve }: 100 \mathrm{~m}\end{array}$} \\
\hline \multirow[t]{11}{*}{ 5.Gradients } & \multicolumn{2}{|c|}{$\begin{array}{l}\text { Gradient } \\
\text { length }(\mathrm{m})\end{array}$} & Maximum \\
\hline & \multicolumn{2}{|c|}{$\operatorname{lin} 30$} & 90 \\
\hline & \multicolumn{2}{|c|}{$\operatorname{lin} 35$} & 125 \\
\hline & \multicolumn{2}{|c|}{$\operatorname{lin} 40$} & 160 \\
\hline & \multicolumn{2}{|l|}{$\operatorname{lin} 45$} & 200 \\
\hline & \multicolumn{2}{|c|}{1 in 50} & 250 \\
\hline & \multicolumn{2}{|c|}{$\operatorname{lin} 55$} & 300 \\
\hline & \multicolumn{2}{|c|}{1 in 60} & 360 \\
\hline & \multicolumn{2}{|c|}{1 in 65} & 425 \\
\hline & \multicolumn{2}{|c|}{1 in 70} & 500 \\
\hline & \multicolumn{3}{|c|}{$\begin{array}{l}\text { (Gradient of } 1 \text { in } 20 \text { and } 1 \text { in } 30 \\
\text { may be allowed for short length of } \\
20 \mathrm{~m} \text { and } 50 \mathrm{~m} \text { respectively) }\end{array}$} \\
\hline $\begin{array}{l}\text { 6.Sight distance } \\
\text { 7. Lane width } \\
\text { 8. Width of } \\
\text { pavement } \\
\text { 9.Clearance }\end{array}$ & \multicolumn{3}{|c|}{$\begin{array}{l}\text { Clear view not less than } 25 \mathrm{~m} \text {. in } \\
\text { gradients of } 1 \text { in } 40 \text { or steeper, clear } \\
\text { view shall not be less than } 60 \mathrm{~m} \text {. } \\
1 \text { meter per lane. } \\
\text { Minimum : } 2 \mathrm{~m} \text { (for } 2 \text { lanes) } \\
\text { 1)vertical: } 2.25 \mathrm{~m} \text { minimum } \\
\text { 2.50 m desirable } \\
\text { 2)Horizontal: } 0.25 \mathrm{~m}\end{array}$} \\
\hline
\end{tabular}

Other general consideration for the design of separate cycle track is:

1. Preferably cycle tracks should be provided on both sides of the road.

2. They should be separated from the main carriageway be a verge or berm, which should be preferably $0.5-1.0$ wide.
3. Cycle tracks should be constructed and maintained with care and should have good riding qualities. Black-topped and concrete surfaces provide smooth riding qualities, whereas water bound macadam and earthen tracks are not inviting for the cyclists to ride upon.

4. The tracks should be clear of obstructions such as hedges' ditches tree roots, kerbs etc. by at least $0.5 \mathrm{~m}$

Design speeds for cycles are about $32 \mathrm{~km} / \mathrm{hr}$ [4]

\subsection{Characteristics of Slow Moving Traffic in India}

The slow moving traffic in India consists of cycle, cycle rickshaw, bullock carts and horse cart.

An understanding of some the characteristics of these vehicle types are essential for traffic engineer.

The dimensions of the slow moving vehicle are given in table below.

Table-4: Dimension of slow moving vehicles [5]

\begin{tabular}{|l|l|l|}
\hline S.N & Vehicle Type & Length \\
\hline 1. & Cycle & 1.91 \\
2. & Cycle rickshaw & 2.59 \\
3. & Bullock cart & 5.87 \\
4. & Horse cart & 4.11 \\
\hline
\end{tabular}

Table-5: Mean speed of slow moving vehicle [5]

\begin{tabular}{|l|l|l|l|}
\hline S.N & $\begin{array}{l}\text { Vehicle } \\
\text { Type }\end{array}$ & $\begin{array}{l}\text { Mean Speed } \\
\text { (K.M.P.H) }\end{array}$ & $\begin{array}{l}\text { Standard } \\
\text { Deviation } \\
\text { (K.M.P.H) }\end{array}$ \\
\hline 1. & Cycle & 15.63 & 2.87 \\
2. & Bullock & 3.78 & 0.65 \\
3. & cart & 12.24 & 3.42 \\
& Horse cart & & \\
\hline
\end{tabular}

The average headway between slow moving vehicles when moving in group is as below:

Headway between cycles: 2 meter

Headway between bullock carts: 1 meter

Headway between horse carts: 8 meter

\subsection{Highway Capacity Manual Methodology [6]}

The methodology provides the framework for pedestrian facility evaluation. The analyst will be able to investigate the effects that bicycles and traffic signals have on the pedestrian facility as well as the effect of pedestrian volume on flow and LOS.

\subsection{Pedestrian LOS}

The HCM's methods for analyzing pedestrian LOS are based on the measurement of pedestrian flow rate and 
sidewalk space. The pedestrian flow rate, which incorporates pedestrian speed, density, and volume, is equivalent to vehicular flow. According to the HCM:

"As volume and density increase, pedestrian speed declines. As density increases and pedestrian space decreases, the degree of mobility afforded to the individual pedestrian declines, as does the average speed of the pedestrian stream."

The analysis of the sidewalk level of service for the midblock uses the calculation of pedestrians per minute per meter (ped $/ \mathrm{min} / \mathrm{m}$ ) as the basis for LOS classification (see Table 6.).

According to this measurement, on a walkway with LOS A, pedestrians move freely without altering their speed in response to other pedestrians or to a decrease in the sidewalk width. On the other hand, on a walkway with LOS $\mathrm{F}$, all walking speeds are severely restricted and forward progress is made only by "shuffling." for the HCM's description for each pedestrian LOS.

The pedestrian unit flow rate (ped $/ \mathrm{min} / \mathrm{m}$ ) is obtained by taking the pedestrian 15-minute flow rate (ped/15-min) and dividing by the effective walkway width. The HCM suggests collecting pedestrian opposing flow volumes at 15minute intervals. The sum of the two directional flows is used as the 15-minute flow rate. Effective width of the sidewalk is calculated by taking the total width of the sidewalk and subtracting obstacle widths and a 0.30 to 0.45 $\mathrm{m}$ buffer width per obstacle. Obstacle widths can be measured from the field. The additional buffer width is based on an estimation provided by the HCM. The HCM cites Pushkarev and Zupan (1975) as their source for the method of buffer width calculation; however, no studies the TD has found, including the cited Pushkarev and Zupan volume, describe any method of buffer width calculation. Using the pedestrian unit flow rate in the "Average Flow LOS Criteria for Walkways and Sidewalks", pedestrian LOS can be calculated. In addition to LOS grades A to F, space $\left(\mathrm{m}^{2} / \mathrm{p}\right)$, speed $(\mathrm{m} / \mathrm{s})$, and the volume-to-capacity $(\mathrm{v} / \mathrm{c})$ ratio can also be derived from the table. Capacity is "the maximum number of persons that can be accommodated along a given point of a sidewalk or transit corridor, or that can be accommodated within a crosswalk, intersection, corner reservoir, transit vehicle or turnstile" (CEQR). The volume-to-capacity ratio is "the ratio of flow rate to capacity for a transportation facility" (HCM).

Pedestrians often travel together as a group, voluntarily or involuntarily, due to signal control, geometrics, or other factors. This phenomenon is called platooning and it occurs, for example, when a large number of bus or subway riders exit onto the sidewalk. To account for the impact of platooning on pedestrian travel behavior, the HCM introduces the "Platoon-Adjusted LOS Criteria for Walkways and Sidewalks," a table which can be used to obtain the platoon LOS. Using research done by Pushkarev and Zupan in Urban Space for Pedestrians, impeded flow in the HCM platoon LOS starts at $49 \mathrm{~m}^{2} / \mathrm{p}, 1.6 \mathrm{ped} / \mathrm{min} / \mathrm{m}$
(LOS A); while "jammed flow" begins at $1 \mathrm{~m}^{2} / \mathrm{p}$, $59 \mathrm{ped} / \mathrm{min} / \mathrm{m}$ (LOS F) (see Table-7.). The HCM states that the LOS which occurs in platoons is generally one level poorer than that determined by average flow criteria

\subsection{Uninterrupted-Flow Pedestrian Facilities}

Uninterrupted pedestrian facilities include both exclusive and shared pedestrian paths (both indoor and outdoor) designated for pedestrian use. These pedestrian facilities are unique because pedestrians do not experience any disruption except the interaction with other pedestrians and, on shared paths, with other nonmotorized modes of transportation. These procedures should be used with pedestrian walking speed, pedestrian start-up time, and pedestrian space requirements

\subsection{Walkways and Sidewalks}

Walkway and sidewalk paths are separated from motor vehicle traffic and typically do not allow bicycles or users other than pedestrians. These facilities are often constructed to serve pedestrians on city streets, at airports, in subways, and at bus terminals. These pedestrian facilities include straight sections of sidewalk, terminals, stairs, and crossflow areas where streams of pedestrians cross.

Table-6: Average Flow LOS Criteria for Walkways and Sidewalks

\begin{tabular}{c|c|c|c|c}
\hline LOS & Space $\left(\mathrm{m}^{2} / \mathrm{p}\right)$ & Flow Rate $(\mathrm{p} / \mathrm{min} / \mathrm{m})$ & Speed $(\mathrm{m} / \mathrm{s})$ & v/c Ratio \\
\hline A & $>5.6$ & $\leq 16$ & $>1.30$ & $\leq 0.21$ \\
B & $>3.7-5.6$ & $>16-23$ & $>1.27-1.30$ & $>0.21-0.31$ \\
C & $>2.2-3.7$ & $>23-33$ & $>1.22-1.27$ & $>0.31-0.44$ \\
D & $>1.4-2.2$ & $>33-49$ & $>1.14-1.22$ & $>0.44-0.65$ \\
E & $>0.75-1.4$ & $>49-75$ & $>0.75-1.14$ & $>0.65-1.0$ \\
F & $\leq 0.75$ & variable & $\leq 0.75$ & variable \\
\hline
\end{tabular}

Table -7: Platoon-Adjusted LOS Criteria for Walkways and Sidewalks

\begin{tabular}{c|c|c}
\hline LOS & Space $\left(\mathrm{m}^{2} / \mathrm{p}\right)$ & Flow Rated $(\mathrm{p} / \mathrm{min} / \mathrm{m})$ \\
\hline$A$ & $>49$ & $\leq 1.6$ \\
$B$ & $>8-49$ & $>1.6-10$ \\
C & $>4-8$ & $>10-20$ \\
$D$ & $>2-4$ & $>20-36$ \\
$E$ & $>1-2$ & $>36-59$ \\
$F$ & $\leq 1$ & $>59$ \\
\hline
\end{tabular}

Note:

a. Rates in the table represent average flow rates over a 5 - 106 - min period.

Such facilities accommodate the highest volumes of pedestrians of the three uninterrupted types of facility addressed here; they also provide the best levels of service, because pedestrians do not share the facility with other modes traveling at higher speeds. 


\subsection{Determining Pedestrian Walking Unit Flow}

\section{Rate}

For simplicity of field observation, pedestrian unit flow rate is used as a service measure. Determination of the peak 15min count and the effective walkway width is required to compute pedestrian unit flow rate according to

$$
\mathrm{vp}=\frac{\mathrm{v} 15}{15 \times \mathrm{WE}}
$$

where

$\mathrm{vp}=$ pedestrian unit flow rate $(\mathrm{p} / \mathrm{min} / \mathrm{m})$,

$\mathrm{v} 15=$ peak 15 -min flow rate $(\mathrm{p} / 15-\mathrm{min})$, and

$\mathrm{WE}=$ effective walkway width $(\mathrm{m})$.

\subsection{Determining Pedestrian Walking Space}

The primary performance measure for walkways and sidewalks is space, the inverse of density. Space can be directly observed in the field by measuring the sample area of the facility and determining the maximum number of pedestrians at a given time in that area.

Space $=$ Density

\subsection{Determining Pedestrian Walking Speed}

Pedestrian walking speed depends on the proportion of elderly pedestrians (65 years of age and older) in the walking population ( 1 ). If 0 to 20 percent of pedestrians are elderly, a walking speed of $1.2 \mathrm{~m} / \mathrm{s}$ is recommended for computations for walkways. If elderly pedestrians constitute more than 20 percent of all pedestrians, a $1.0 \mathrm{~m} / \mathrm{s}$ walking speed is recommended. In addition, an upgrade of 10 percent or greater reduces walking speed by $0.1 \mathrm{~m} / \mathrm{s}$.

\subsection{Determining Effective Walkway Width}

Effective walkway width is the portion of a walkway that can be used effectively by pedestrians. Several types of walkway obstructions (see Table- 8 and figure 1) end to make pedestrians shy away

Effective walkway width is computed using Equation below

$$
\mathrm{WE}=\mathrm{WT}-\mathrm{Wo}
$$

Where

$\mathrm{WE}=$ effective walkway width $(\mathrm{m})$,

$\mathrm{WT}=$ total walkway width $(\mathrm{m})$, and

Wo $=$ sum of widths and shy distances from obstructions on the walkway $(\mathrm{m})$.

A schematic showing typical obstructions and the estimated width of walkway they preempt is provided in figure 1 . Table-8 lists the width of walkway preempted by curbs, buildings, or fixed objects. The values in figure 1 can be used when specific walkway configurations are not available.

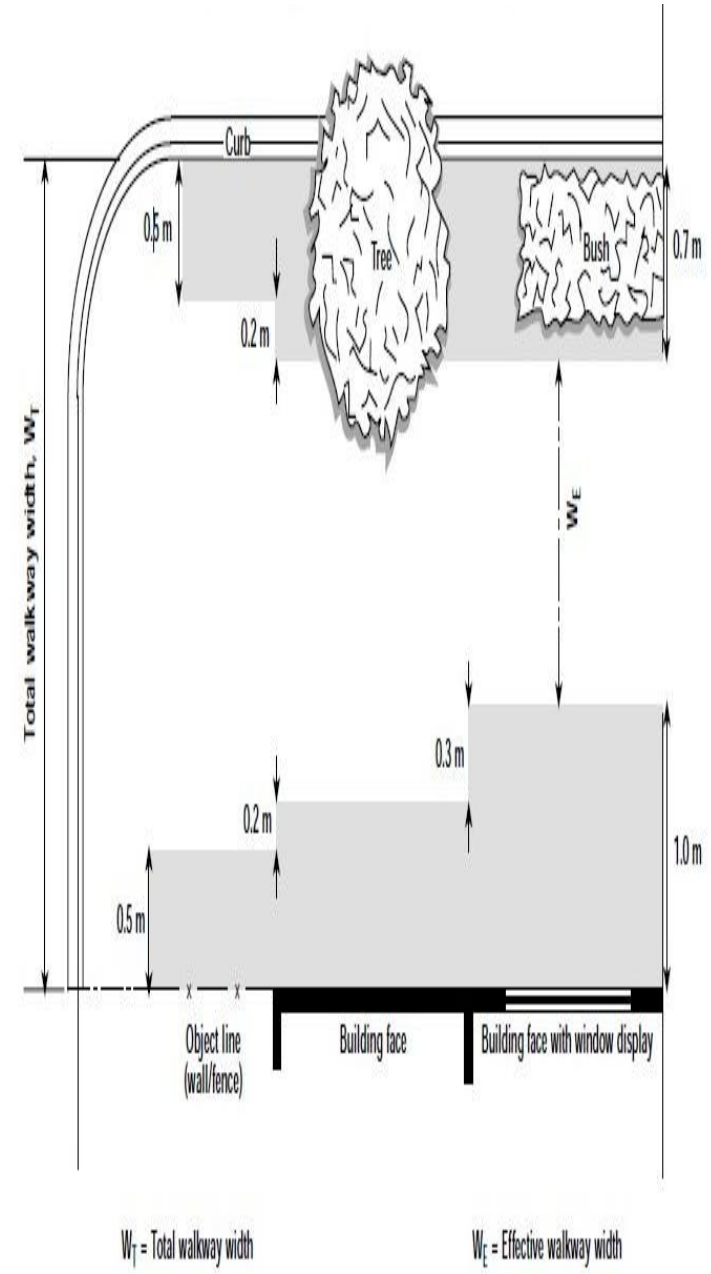

Fig 1 Determination of effective walking width

The effective length of an occasional obstruction is assumed to be 5 times its effective width. The average effect of occasional obstructions such as trees and poles therefore should be obtained by multiplying their effective width by the ratio of their effective length to the average distance between them.

Also, at signalized intersection crossings, the analyst should observe if right-turning vehicles occupy part of the crosswalk during the crossing phase. If a significant portion of the crosswalk is not being used by pedestrians due to right-turning vehicles, effective crosswalk width can be computed by subtracting the appropriate time-space used by right-turning vehicles. 
Table-8: Preemption of walkway width

\begin{tabular}{|c|c|}
\hline Obstacle & Approx. Width Preempted (m) \\
\hline \multicolumn{2}{|c|}{ Street Furniture } \\
\hline Light pole & $0.8-1.1$ \\
\hline Traffic signal poles and boxes & $0.9-1.2$ \\
\hline Fire alarm boxes & $0.8-1.1$ \\
\hline Fire hydrants & $0.8-0.9$ \\
\hline Traffic signs & $0.6-0.8$ \\
\hline Parking meters & 0.6 \\
\hline Mail boxes $(0.5 \mathrm{~m} \times 0.5 \mathrm{~m})$ & $1.0-1.1$ \\
\hline Telephone booths ( $0.8 \mathrm{~m} \mathrm{x} 0.8 \mathrm{~m})$ & 1.2 \\
\hline Waste baskets & 0.9 \\
\hline Benches & 1.5 \\
\hline \multicolumn{2}{|c|}{ Public Underground Access } \\
\hline Subway stairs & $1.7-2.1$ \\
\hline Subway ventilation gratings (raised) & $1.8+$ \\
\hline Transformer vault ventilation gratings (raised) & $1.5+$ \\
\hline \multicolumn{2}{|c|}{ Landscaping } \\
\hline Trees & $0.6-1.2$ \\
\hline Planter boxes & 1.5 \\
\hline \multicolumn{2}{|c|}{ Commercial Uses } \\
\hline Newsstands & $1.2-4.0$ \\
\hline Vending stands & variable \\
\hline Advertising displays & variable \\
\hline Store displays & variable \\
\hline Sidewalk cafes (two rows of tables) & 2.1 \\
\hline \multicolumn{2}{|c|}{ Building Protrusions } \\
\hline Columns & $0.8-0.9$ \\
\hline Stoops & $0.6-1.8$ \\
\hline Cellar doors & $1.5-2.1$ \\
\hline Standpipe connections & 0.3 \\
\hline Awning poles & 0.8 \\
\hline Truck docks (trucks protruding) & variable \\
\hline Garage entrance/exit & variable \\
\hline Driveways & variable \\
\hline
\end{tabular}

\subsection{Study on Cyclist \& Slow Moving Traffic}

This study involve in to determine the volume of cycle, wheel cart and rickshaw, to utilize the scenario for calculate optimum width of slow moving traffic and their effect on other aspects

Table- 9: PCU of slow moving traffic (IRC, 1990) for\% composition of vehicle type in traffic stream[7]

\begin{tabular}{|l|l|l|l|}
\hline S.no & Vehicle type & $5 \%$ & $10 \%$ \\
\hline 1. & cycle & 0.4 & 0.5 \\
\hline 2 & Cycle rickshaw & 1.5 & 2.0 \\
\hline 3 & Horse drawn & 1.5 & 2.0 \\
\hline 4 & Hand cart & 2.0 & 3.0 \\
\hline
\end{tabular}

Table-10: PCU Equivalents for bicycle (HCM, 1985) [8]

\begin{tabular}{|l|l|l|l|l|}
\hline \multirow{2}{*}{ S.no } & \multirow{2}{*}{$\begin{array}{l}\text { Bicycle } \\
\text { movement }\end{array}$} & \multicolumn{3}{|l|}{ Lane width(ft) } \\
\cline { 3 - 5 } & & $<11$ & $11-14$ & $>14$ \\
\hline 1. & Opposed & 1.2 & 0.5 & 0.0 \\
\hline 2 & unopposed & 1.0 & 0.2 & 0.0 \\
\hline
\end{tabular}

Table-11: PCU Equivalents as per Indian Practice [9]

\begin{tabular}{|l|l|l|}
\hline S.no & Vehicle Type & PCU Equivalency Factor \\
\hline 1 & cycle & 0.5 \\
\hline 2 & Cycle rickshaw & 2.0 \\
\hline 3 & Horse drawn(Tonga) & 3.0 \\
\hline 4 & Hand cart & 4.0 \\
\hline
\end{tabular}

Table-12: PCU Equivalents as per British Practice [10]

\begin{tabular}{|l|l|l|l|l|l|}
\hline S.n & $\begin{array}{l}\text { Vehicle } \\
\text { Type }\end{array}$ & $\begin{array}{l}\text { Urban } \\
\text { Standard }\end{array}$ & $\begin{array}{l}\text { Rural } \\
\text { Standard }\end{array}$ & $\begin{array}{l}\text { Round } \\
\text {-about }\end{array}$ & $\begin{array}{l}\text { Traffic } \\
\text { Signal }\end{array}$ \\
\hline 1 & cycle & 0.33 & 0.5 & 0.5 & 0.2 \\
\hline 2 & $\begin{array}{l}\text { Horse } \\
\text { drawn }\end{array}$ & 2.0 & 3.0 & 2.8 & 2.25 \\
\hline
\end{tabular}

\subsection{Cycle Track Width [11]}

There are only two possible positions for cycling along roads and streets:

1. Mixed Traffic - cyclists are in front or behind vehicles in a controlled speed environment;

2. Cycling Lanes or Tracks - cyclists are beside vehicles in their own space.

In either situation:

1. The expected position of the cyclist should be legible to all road users;

2. There must be sufficient width for cycling.

If there is not sufficient space for a functional cycle lane as set out below, then a Mixed Traffic solution should be considered with an appropriate traffic regime. In other words, a substandard cycle lane is never recommended.

\subsection{Additional Effective Width}

Reduced Kerbs Heights between the cycle lane and footpath or verge, $50 \mathrm{~mm}$ or lower, will not catch the underside of the pedal of the bicycle, and cyclists can cycle closer to the kerb.

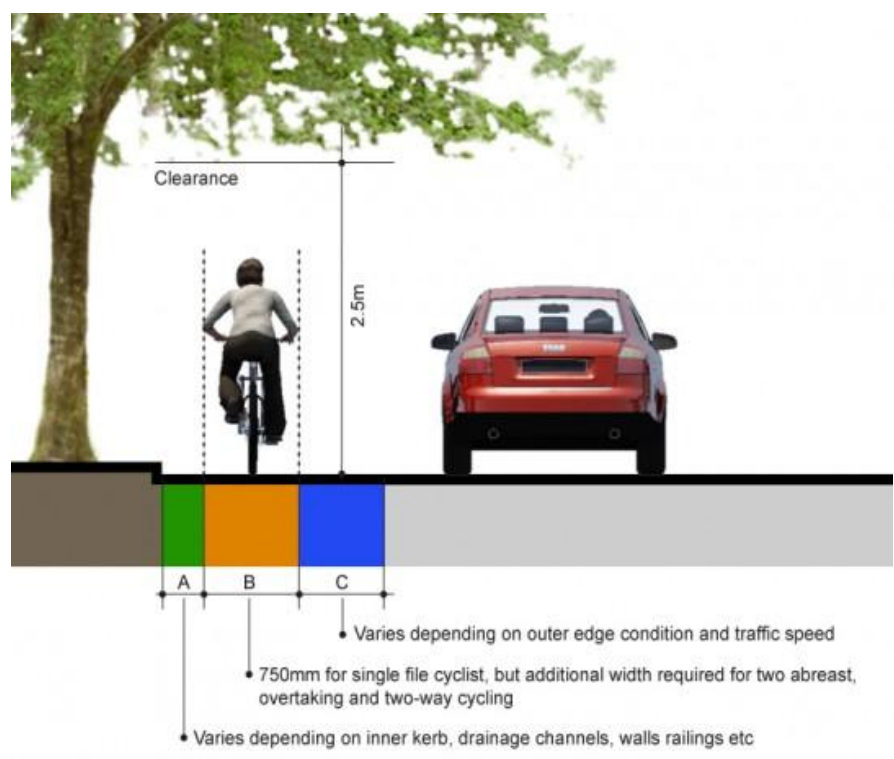

Additional width may also be required for particular circumstances such as at uphill gradients, near primary schools and alongside parking areas etc

Fig-2 Cycle Track Zone 

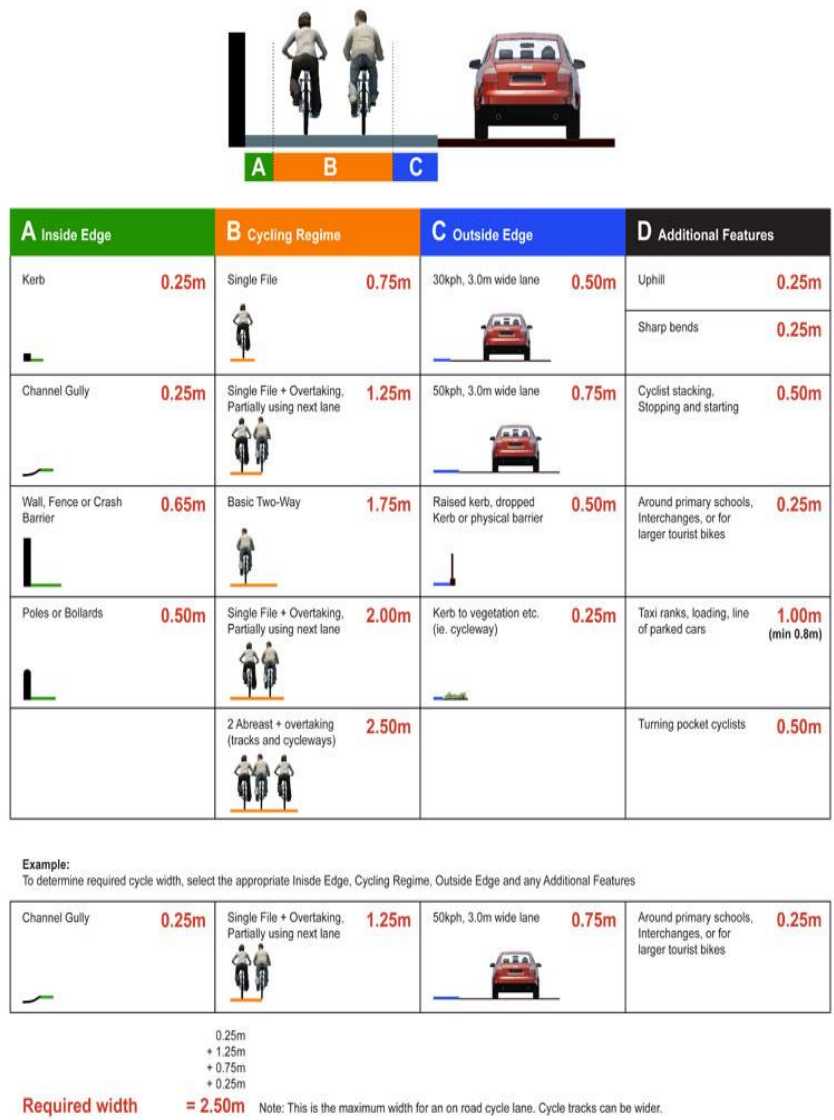

Fig-3 Cycle Track Width Calculator

Side Draining Gullies with a uniform camber provide more effective width for cycling than surface gullies / drainage channels.

\section{Width Calculator}

\section{Space limited to single file only}

There are three basic elements that determine the width of a cycle lane or track, A, B, and C below.

A) The space to the left of the cyclist

B) The space required to support the cycling regime (twoabreast, single file, overtaking etc)

C) The space to the right of the cyclist.

There may also be additional width required depending on topography, traffic, locality etc.

Where a cycle lane exceeds $3.0 \mathrm{~m}$ in width, there may be some confusion with traffic lanes and a cycle track may be a better solution.

\subsection{Determining Width}

The designed width of a cycle facility is comprised of the effective width, i.e. the space that is "usable" by cyclists, as well as the clearances that will be required in different circumstances.

\subsubsection{Cyclist's Wide}

An individual adult cyclist on a conventional bicycle is approximately $750 \mathrm{~mm}$ wide. A further $250 \mathrm{~mm}$ will normally permit the use of accessories such as child trailers, panniers etc.

\subsubsection{Wobble Room}

Cyclists always wobble or wander from side to side in order to keep balance, particularly at lower speeds. A provision of $250 \mathrm{~mm}$ wobble room is normally sufficient.

Additional width should be considered where cyclists will be slower and wobbling more, e.g. approaching junctions, at bends, or on uphill sections.

\subsection{Madhya Marg Detail Study}

The location of road is in front of Bhavan vidyalaya on Madhya Marg near the bus stop. The number of cyclist, rickshaw and horse carts has been counted separately on slip road and main road of Madhya Marg on road and the footpath and slip road is not maintained well. The dimension of the $100 \mathrm{~m}$ section and photograph represents the actual location and condition as given below.

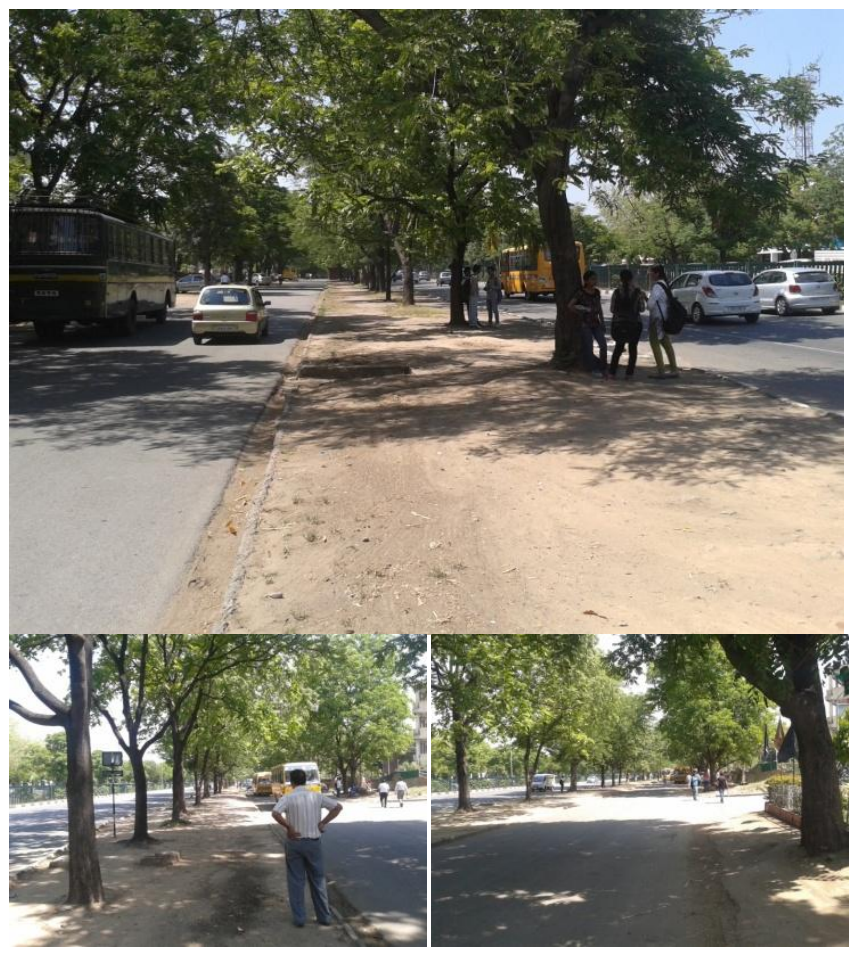

Table -13: Morning Data of pedestrian count and LOS

\begin{tabular}{|l|l|l|l|l|}
\hline $\begin{array}{l}\text { Time } \\
\text { interv- } \\
\text { al }\end{array}$ & $\begin{array}{l}\text { No. of } \\
\text { Pedestrian } \\
\text { in } \\
\text { morning }\end{array}$ & $\begin{array}{l}\text { Flow rate } \\
(\mathrm{Ped} / \mathrm{min} / \mathrm{m})\end{array}$ & $\begin{array}{l}\text { Space } \\
\left(\mathrm{m}^{2} /\right. \\
\text { Ped })\end{array}$ & $\begin{array}{l}\text { Level } \\
\text { of } \\
\text { service }\end{array}$ \\
\hline $\begin{array}{l}8: 30- \\
8: 45\end{array}$ & 7 & 0 & 309.5 & $\mathrm{~A}$ \\
\hline $\begin{array}{l}8: 45- \\
9: 00\end{array}$ & 4 & 0 & 541.6 & $\mathrm{~A}$ \\
\hline $\begin{array}{l}9: 00- \\
9: 15\end{array}$ & 14 & 0.010 & 154.76 & $\mathrm{~A}$ \\
\hline
\end{tabular}




\begin{tabular}{|l|l|l|l|l|}
\hline $\begin{array}{l}9: 15- \\
9: 30\end{array}$ & 6 & 0 & 361.1 & A \\
\hline
\end{tabular}

Table-14: Evening Data of pedestrian count and LOS

\begin{tabular}{|l|l|l|l|l|}
\hline $\begin{array}{l}\text { Time } \\
\text { interval }\end{array}$ & $\begin{array}{l}\text { No. of } \\
\text { Pedestrian } \\
\text { in } \\
\text { evening }\end{array}$ & $\begin{array}{l}\text { Flow rate } \\
(\text { Ped/min/m) }\end{array}$ & $\begin{array}{l}\text { Space } \\
\left(\mathrm{m}^{2} /\right. \\
\text { Ped })\end{array}$ & $\begin{array}{l}\text { Level } \\
\text { of } \\
\text { service }\end{array}$ \\
\hline $\begin{array}{l}4: 30- \\
4: 45\end{array}$ & 42 & 0.03 & 51.58 & A \\
\hline $\begin{array}{l}4: 45- \\
5: 00\end{array}$ & 46 & 0.03 & 47.10 & A \\
\hline $\begin{array}{l}5: 00- \\
5: 15\end{array}$ & 40 & 0.02 & 54.16 & A \\
\hline $\begin{array}{l}5: 15- \\
5: 30\end{array}$ & 36 & 0.20 & 60.18 & A \\
\hline
\end{tabular}

As the detail given above Table the LOS on the section comes under the LOS-A. As the Highway Capacity Manual the Pedestrian Space $>5.6 \mathrm{~m} 2 / \mathrm{p}$ Flow Rate $<16 \mathrm{p} / \mathrm{min} / \mathrm{m}$

Total number of cyclist in morning $=306$

Total P.C.U/hr in morning $=153.5$

Total number of cyclist in Evening $=215$

Total P.C.U/hr in Evening = 107.5

Total number of Rickshaw in morning $=100$

Total P.C.U/hr in morning $=200$

Total number of Rickshaw in Evening $=66$

Total P.C.U/hr in Evening = 132

\section{Opposite Side Road}

The location of section is exactly opposite to previous road on Madhya Marg near the bus stop. The number of cyclist, rickshaw and horse carts has been counted separately on slip road and main road of Madhya Marg on this section and the footpath and slip road is not maintained well. The dimension of the $100 \mathrm{~m}$ section and photograph represents the actual location and condition as given below
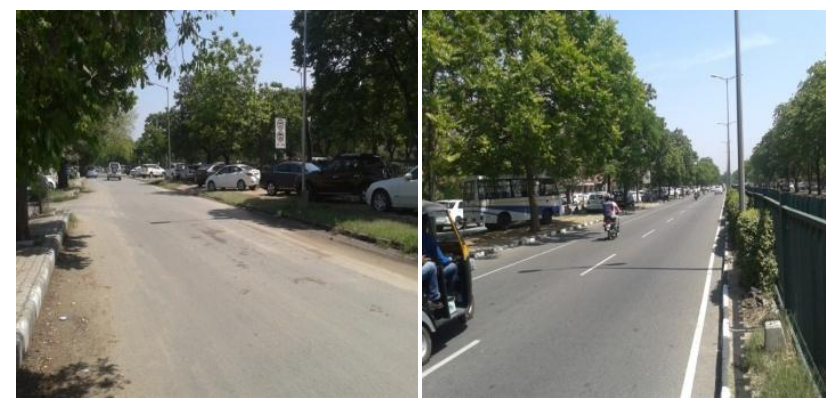

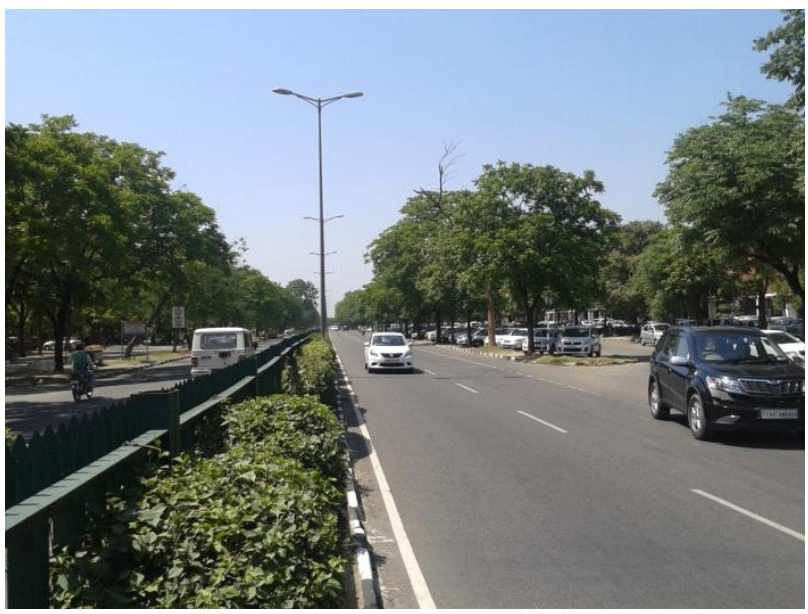

Table 5.15 Morning Data of pedestrian count and LOS on opposite road

\begin{tabular}{|l|l|l|l|l|}
\hline $\begin{array}{l}\text { Time } \\
\text { interv- } \\
\text { al }\end{array}$ & $\begin{array}{l}\text { No. of } \\
\text { Pedestrian } \\
\text { in } \\
\text { morning }\end{array}$ & $\begin{array}{l}\text { Flow rate } \\
(\text { Ped/min/m) }\end{array}$ & $\begin{array}{l}\text { Space } \\
\left(\mathrm{m}^{2} /\right. \\
\text { Ped })\end{array}$ & $\begin{array}{l}\text { Level } \\
\text { of } \\
\text { service }\end{array}$ \\
\hline $\begin{array}{l}8: 30- \\
8: 45\end{array}$ & 35 & 0.02 & 61.90 & A \\
\hline $\begin{array}{l}8: 45- \\
9: 00\end{array}$ & 19 & 0.01 & 114.03 & A \\
\hline $\begin{array}{l}9: 00- \\
9: 15\end{array}$ & 31 & 0.02 & 69.89 & A \\
\hline $\begin{array}{l}9: 15- \\
9: 30\end{array}$ & 48 & 0.03 & 45.13 & A \\
\hline
\end{tabular}

Table 5.16: Evening Data of pedestrian count and LOS on opposite road

\begin{tabular}{|l|l|l|l|l|}
\hline $\begin{array}{l}\text { Time } \\
\text { interv- } \\
\text { al }\end{array}$ & $\begin{array}{l}\text { No. of } \\
\text { Pedestrian } \\
\text { in } \\
\text { evening }\end{array}$ & $\begin{array}{l}\text { Flow rate } \\
(\mathrm{Ped} / \mathrm{min} / \mathrm{m})\end{array}$ & $\begin{array}{l}\text { Space } \\
\left(\mathrm{m}^{2} /\right. \\
\text { Ped })\end{array}$ & $\begin{array}{l}\text { Level } \\
\text { of } \\
\text { service }\end{array}$ \\
\hline $\begin{array}{l}4: 30- \\
4: 45\end{array}$ & 42 & 0.03 & 51.58 & $\mathrm{~A}$ \\
& 10 & 0.01 & 216.6 & $\mathrm{~A}$ \\
\hline $\begin{array}{l}4: 45- \\
5: 00\end{array}$ & 20 & 0.02 & 6 & $\mathrm{~A}$ \\
\hline $\begin{array}{l}5: 00- \\
5: 15\end{array}$ & 33 & 0.02 & 3 & $\mathrm{~A}$ \\
\hline $5: 15-$ & & & 65.65 & \\
$5: 30$ & & & & \\
& & & & \\
\hline
\end{tabular}

As the detail given above Table the LOS on the section comes under the LOS-A. As the Highway Capacity Manual the Pedestrian Space $>5.6 \mathrm{~m} 2 / \mathrm{p}$ Flow Rate $<16$ p/min/m. Total number of cyclist in morning $=668$ Total P.C.U/hr in morning $=334$ 
Total number of cyclist in Evening $=387$

Total P.C.U/hr in Evening $=193.5$

Total number of Rickshaw in morning $=221$

Total P.C.U/hr in morning $=442$

Total number of Rickshaw in Evening $=74$

Total P.C.U/hr in Evening $=148$

\section{CONCLUSIONS}

\section{Pedestrian}

As the result from above the level of service of pedestrian is found $\mathrm{A}$ if do not consider the another factor than volume, Space and Flow rate. The volume of pedestrian is too low

Maximum 15-minute volume count is between 4:45-5:00

PM on section

Foot path width $=6.50 \mathrm{~m}$

Maximum volume $=46$ pedestrian

Space $=47.10 \mathrm{~m}^{2} /$ ped

Flow rate $=0.03 \mathrm{ped} / \mathrm{min} / \mathrm{m}$

Capacity $=164 \mathrm{ped} / \mathrm{hr}$

The volume on the section was too low that the width of the section can be reduced to certain extant without any change in the level of service A of the section.

As IRC recommended that if the pedestrian capacity is less than 800 pedestrian than the minimum width of footpath is $1.50 \mathrm{~m}$. But for principal business and industrial districts the minimum width $2.7 \mathrm{~m}$ can be provided.

After consideration in IRC and Highway Capacity Manual the minimum width can be provided by $2.7 \mathrm{~m}$

Beside the width of the foot path the condition of pavement is not so well, it all through the length is unpaved which make the pedestrian to undesirable to use foot path.

\section{Cyclist}

The overall with of slip road is $6.9 \mathrm{~m}$. So it can be provided by the cycle track on the side of foot path

The peck hour volume found in between 8:30-9:30 AM

Total number of cyclist at peck- hour on section $=306$ cyclist/hour

In term of PCU/hour=153.5PCU/ hour

According to IRC the minimum Width of cycle track is $2 \mathrm{~m}$. But section can be provided by the cycle track of $2.50 \mathrm{~m}$ which allow to access two-abreast and one overtaking. Still the width of $1.3 \mathrm{~m}$ remains after providing cycle track

\section{Other Slow Moving Traffic}

Total number of Rickshaw in peck- hour on section $=100$ Rickshaw/hour

In term of PCU/hour $=200 \mathrm{PCU} /$ hour
There is no horse cart on section

After providing $2.5 \mathrm{~m}$ cycle track. The remaining width of $1.3 \mathrm{~m}$ slip road can be used for other slow moving traffic.

\section{Opposite road}

\section{Pedestrian}

As the result from above the level of service of pedestrian is found $\mathrm{A}$ if do not consider the another factor than volume, Space and Flow rate. The volume of pedestrian is too low .The parking on the foot path should be avoided and carried out parking study near section to sort out parking problem. About 30 to 40 car were parked at the time of study

Maximum 15-minute volume count is between 9:15-9:30 AM on section

Foot path width $=6.50 \mathrm{~m}$

Maximum volume $=48$ pedestrian

Space $=45.13 \mathrm{~m}^{2} / \mathrm{ped}$

Flow rate $=0.03 \mathrm{ped} / \mathrm{min} / \mathrm{m}$

Capacity $=105 \mathrm{ped} / \mathrm{hr}$

The volume on the section was too low that the width of the section can be reduced to certain extant without any change in the level of service A of the section.

As IRC recommended that if the pedestrian capacity is less than 800 pedestrian than the minimum width of footpath is $1.50 \mathrm{~m}$. But for principal business and industrial districts the minimum width $2.7 \mathrm{~m}$ can be provided.

After consideration in IRC and Highway Capacity Manual the minimum width can be provided by $2.7 \mathrm{~m}$

Beside the width of the foot path the condition of pavement is not so well, it all through the length is unpaved which make the pedestrian to undesirable to use foot path.

\section{Cyclist}

The overall with of slip road on section is $6.9 \mathrm{~m}$. So it can be provided by the cycle track by adjusting the foot path to slip road

The peck hour volume found in between 8:30-9:30 AM Total number of cyclist at peck- hour on section = 668 cyclist/hour

In term of PCU/hour=334PCU/ hour

According to IRC the minimum Width of cycle track is $2 \mathrm{~m}$. But section can be provided by the cycle track of $2.50 \mathrm{~m}$ which allow to access two-abreast and one overtaking. Still the width of $1.3 \mathrm{~m}$ remains after providing cycle track

\section{Other Slow Moving Traffic}

Total number of Rickshaw in peck- hour on section $=100$ Rickshaw/hour

In term of PCU/hour =221 PCU/ hour 
There is no horse cart on section

After providing $2.5 \mathrm{~m}$ cycle track. The remaining width of $1.3 \mathrm{~m}$ slip road can be used for other slow moving traffic.

\section{REFERENCES}

[1] Road in Urban Area, Department of Environment (U.K), H.M.S.O., London 1966

[2] Guideline for Pedestrian Facilities, I.R.C:103-1988, Indian Roads Congress, New Delhi, 1989

[3] Recommended Practice for the Design and Layout of cycle Track, Indian Road Congress, New Delhi,1979).

[4] Guide for Development of New Bicycle Facilities, American Association of State Highway and Transportation Official, Washington, 1981

[5] Kadiyali, et al, some characteristics of slow moving traffic on Indian roads, RUCS Technical paper no.47,Eleventh Quarterly Report, Road User Cost study, Central Road Research Institute, New Delhi, 1980

[6] Highway Capacity Manual,HCM2000,Transportation research Board, Washington DC, 2000

[7] Guidelines on Capacity of road in Rural Area, I.R.C., New Delhi,1990

[8] Highway Capacity Manual,HCM1985,Transportation research Board, Washington DC, 1985

[9] Guidelines on Capacity of road in Rural Area, I.R.C.:64-1990,I.R.C., New Delhi,1990

[10] Kadiyali, L.R.PCU factor under Indian conditionsome tentative findings, RUCS Technical Paper No.37, Eleventh Quarterly Report, Central Road Research Institute, New Delhi 1980

[11] National Manual Cycle, DTO Technical Working Group 